\title{
Comparison of the effect of rhodium citrate-associated iron oxide nanoparticles on metastatic and non-metastatic breast cancer cells
}

\author{
Natalia Lemos Chaves ${ }^{1}$, Danilo Aquino Amorim', Cláudio Afonso Pinho Lopes², Irina Estrela-Lopis ${ }^{3}$, \\ Julia Böttner ${ }^{3}$, Aparecido Ribeiro de Souza ${ }^{4}$ and Sônia Nair Báo ${ }^{1 *}$
}

\section{${ }^{*}$ Correspondence:}

snbao@unb.br

${ }^{1}$ Institute of Biological

Sciences, Department of Cell

Biology, University of Brasilia

(UnB), Brasilia, Brazil

Full list of author information

is available at the end of the article

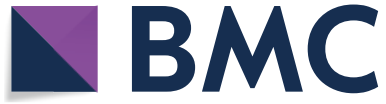

(0) The Author(s) 2019. This article is distributed under the terms of the Creative Commons Attribution 4.0 International License (http://creativecommons.org/licenses/by/4.0/), which permits unrestricted use, distribution, and reproduction in any medium, provided you give appropriate credit to the original author(s) and the source, provide a link to the Creative Commons license, and indicate if changes were made. The Creative Commons Public Domain Dedication waiver (http://creativecommons.org/publicdomain/zero/1.0/) applies to the data made available in this article, unless otherwise stated. 
Keywords: Maghemite, MCF-7, MDA-MB-231, Metastatic cells

\section{Background}

Over the past few years, the nanotechnology field has emerged as a promising approach with the potential to produce diagnostic and therapeutic applications (Paris and Vallet-Regí 2018). The nanoscale of nanomaterials allows better access to biological sites. Among other applications, cancer cell targeting would benefit greatly from highly specific and localized drug delivery. In this context, iron oxide nanoparticles hold great promise as diagnostic and therapeutic agents in oncology. Their intrinsic physical properties are particularly interesting for simultaneous drug delivery, molecular imaging and applications such as localized hyperthermia (Bender et al. 2018; Iv et al. 2015). These technical features provide special perspectives for breast cancer treatment and diagnosis, which is especially important because of the high incidence, drug resistance and recurrence risk related to this disease (Low et al. 2018; Harmon et al. 2015; Karakatsanis et al. 2016). Current studies with maghemite nanoparticles, an iron oxide compound, have demonstrated in vitro and in vivo specific cytotoxic action for target cells, and these results have indicated this nanoparticle as a promising option for drug delivery (Manikandan et al. 2018; Chaves et al. 2017; Magro et al. 2018). Maghemite nanoparticles associated with rhodium citrate (MRC) have showed colloidal stability and antitumor activity in breast cancer cells (Carneiro et al. 2011; Peixoto et al. 2015; Chaves et al. 2015; da Silva Nunes et al. 2013; Rocha et al. 2017).

The unique structural features of many solid tumors, including hypervasculature with defective architecture, and impaired lymphatic drainage, allow for the well-characterized enhanced permeability and retention effect (EPR) and are key factors for advancing this technology platform (Maeda et al. 2013). However, nanomedicine activity is not only related to tumor EPR effect. It is also influenced by the intra-tumoral distribution of the delivery system, the extent and kinetics of drug release within the tumor and the exposure to drug released in circulation (Wicki et al. 2015). Recent works (Cook et al. 2014; Hare et al. 2017) suggest that efforts should be directed toward understanding the correlations between the tumor cell biology and the nanoparticles' behavior. Since cancer is a heterogeneous disease, designing nanomedicines to overcome a well-defined challenge with a particular tumor cell type has a greater chance of success (Shi et al. 2017).

In our previous work, MRC nanoparticles induced apoptosis in MCF-7 cells after $24 \mathrm{~h}$ of exposure (Chaves et al. 2015). The different uptake mechanism of MRC in metastatic and non-metastatic breast cancer cell models also was identified (Chaves et al. 2017). However, to our knowledge, the behavior of these nanodevices in human tumor cells over time has not yet been explored, and nor has MRC cytotoxicity and therapeutic effectiveness comparison in different cancer cells been performed until the present moment. And there was no evaluation aiming to verify antimetastatic action of the MRC nanoparticles. Drug-loaded NPs may increase accumulation of intracellular drugs by inhibiting the functions of PGP and exhibit a multidrug resistance (MDR)-reversing effect (Cheng et al. 2017; Liang et al. 2018; Peng et al. 2018). More prolonged investigation allows for monitoring the development of resistance mechanisms, such as the expression of proteins that mediate the efflux of drugs such as PGP (Chen et al. 2018). Thus, in this work we evaluate the actions of the nanoparticles against tumor cells for up to $72 \mathrm{~h}$ of exposure connecting with possible 
mechanisms of resistance and the migratory capacity after the treatment with focus on the comparison of the effectiveness of NPs in different cell types, aiming to elect the most responsive.

\section{Results}

\section{In vitro cytotoxicity study}

The in vitro cytotoxicity of MRC in two selected breast human cancer cell lines (MDAMB-231 and MCF-7) and human non-tumor mesenchymal cells (HNTMC) was determined by MTT assay. The metal compound chemotherapeutic agent rhodium citrate (RC) was used as a positive control. Non-tumor cells (HNTMC) have their viability statistically altered by treatment for up to $72 \mathrm{~h}$ with MRC, and RC at concentrations of up to $200 \mu \mathrm{M}$ (Fig. 1a-c). As shown in Fig. 1, MRC complexes exhibited a broad viability inhibition on human cancer cells, mainly in the first $24 \mathrm{~h}$ (Fig. 1a). However, while MRC induced cytotoxicity in MDA-MB-231 in a time-dependent manner, progressively decreasing the required dose for significant reduction in cell viability after 48 and $72 \mathrm{~h}$, MCF-7 appears to recover its viability from $48 \mathrm{~h}$ of exposure (Fig. 1b, c). The MRC half-maximal inhibitory concentration $\left(\mathrm{IC}_{50}\right)$ calculated for $24 \mathrm{~h}$ of treatment was 125 for MDA-MB-231 and $162 \mu \mathrm{M}$ for MCF-7.

\section{Cell migration and cell cycle analysis}

The different effects of MRC on metastatic (MDA-MB-231) and non-metastatic (MCF-7) breast cancer cells observed in the viability assay over time drove us to explore the effect of MRC on migration capacity in metastatic cancer cells. MDA-MB-231 cells treated with MRC had their migration capacity reduced (Fig. 2). After treatment with the NPs, the number of cells that were able to transpose the in vitro-simulating extracellular matrix (mean $=844$ cells) was statistically lower than in the untreated control (mean $=1500$ cells).

\section{Evaluation of P-glycoprotein (pgp) in tumor cells treated with MRC}

The PGP level was not altered in MDA-MB-231 cells after MRC treatment for 24 and $48 \mathrm{~h}$ of exposure. However, in MCF-7 cells, a significant increase in this protein stimulated by MRC nanoparticles (24 h) was detected (Fig. 3).

\section{MRC nanoparticles effects on DNA replication and cell cycle}

Treatment with NPs for $24 \mathrm{~h}$ reduced DNA synthesis in MDA-MB-231 and MCF-7 cells. After $24 \mathrm{~h}$, there was an increase in thymidine incorporation in untreated cells, while in treated cells (MRC), the detection of bromodeoxyuridine (BrdU) was reduced (compared to untreated control cells after $24 \mathrm{~h}$ ), especially in MDA-MB-231 cells (Fig. 4a). Figure 4b shows the cell cycle changes induced by MRC. In both cell lines, the treatment induced an increase in the $\mathrm{S}$ phase, reflecting a stop at that point in the cycle and consequent reduction in the gap 2 phase (G2), mainly in MDA-MB-231 (Fig. 4b).

\section{Discussion}

Studies of viability after MRC treatment of non-tumoral cell types (MFC-10A) have already demonstrated a low toxicity of this nanocomposite in these cells (Chaves et al. 2015; da Silva Nunes et al. 2013). However, it is known that cells from established strains 

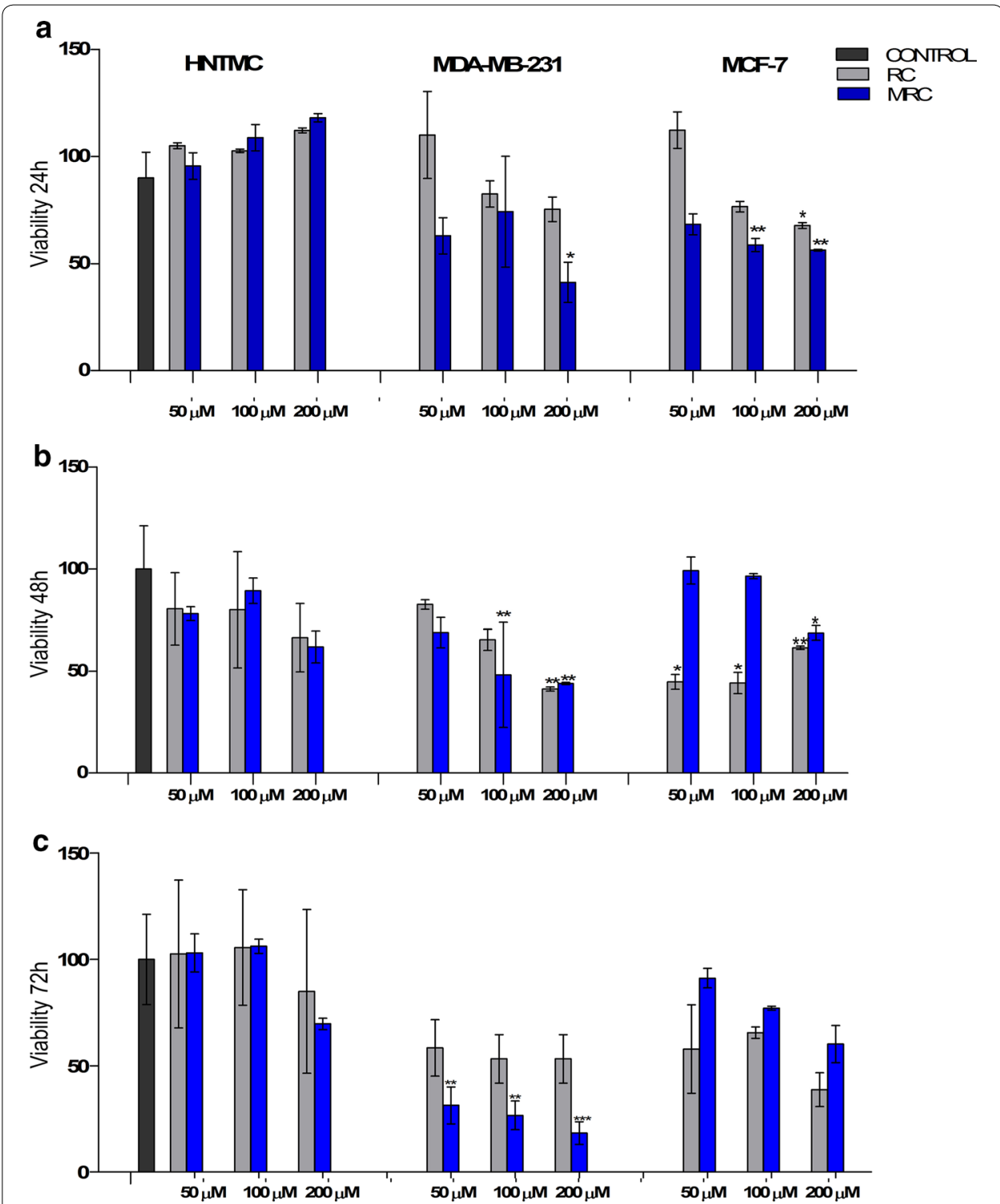

Fig. 1 Viability of metastatic breast tumor cells (MDA-MB-231), non-metastatic mammary carcinoma cells (MCF-7) and human non-tumor mesenchymal cells (HNTMC). The assay was performed after 24- (a), 48- (b) and 72-h (c) exposure to 50, 100 and $200 \mu \mathrm{M}$ rhodium citrate free (RC) or associated with maghemite nanoparticles (MRC). ${ }^{*} p<0.05,{ }^{* *} p<0.01,{ }^{* * *} p<0.005$

undergo immortalization processes that modify and make them more resistant (Bana and Bagrel 2011). The use of primary culture cells as used in the present work was essential to complement the in vitro elucidation of a possible passive specific effect of NPs. The different behaviors regarding viability after MRC treatment over time observed in two cell models should be considered for designing the most appropriate administration schedule. In tumors with the same characteristics as MCF-7 cells, repetitive exposure to NPs appears to be more appropriate, while in tumors that reassemble MDA-MB-231 cells, a continuous infusion may be sufficient (Eastman 2017).

Not only cytotoxicity in tumor cells is an important target for the development of antitumor drugs. One of the major problems in cancer control is the metastatic 

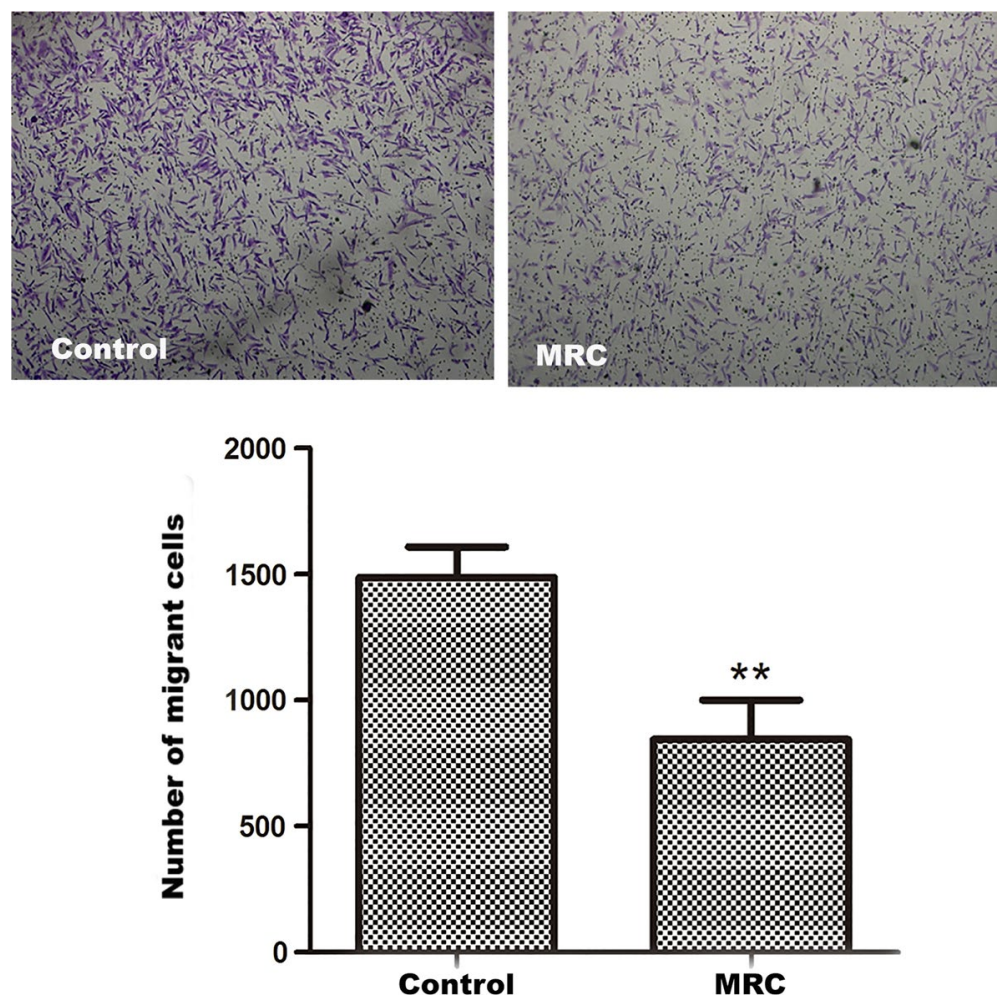

Fig. 2 Analysis of migration capacity of MDA-MB-231 cells after treatment with $100 \mathrm{mM}$ rhodium citrate associated with maghemite nanoparticles (MRC). Micrographs of migrant untreated (control) or treated MDA-MB-231 cells. The graph represents the cell counts. $\left(^{* *}\right) p \leq 0.01$
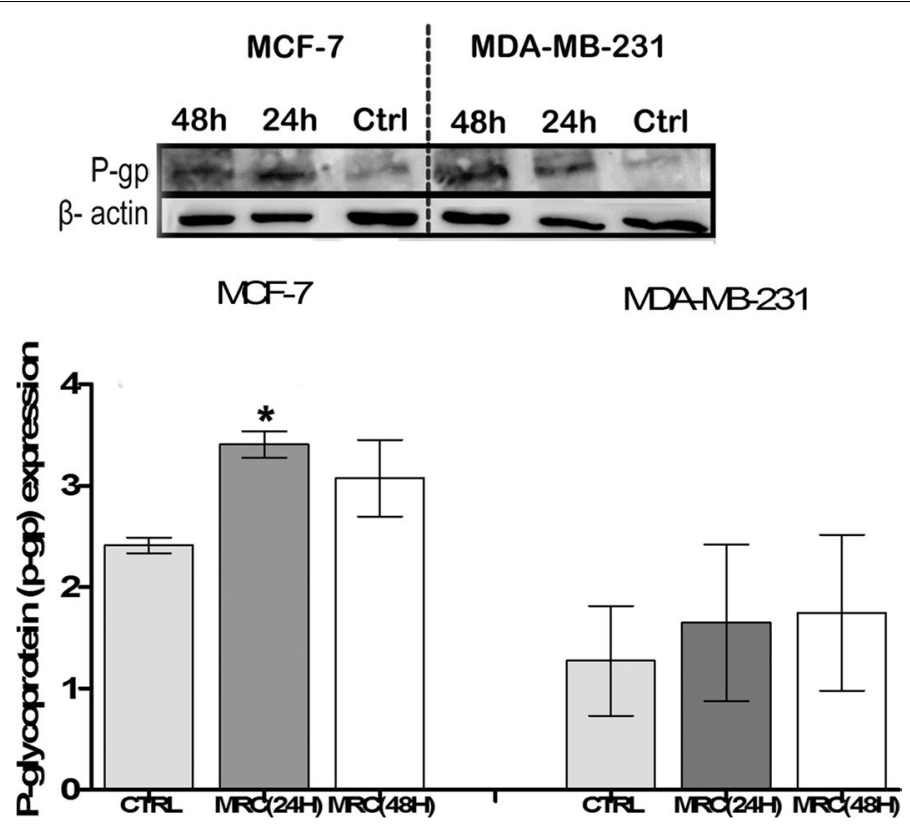

Fig. 3 Immunoblot of P-glycoprotein production in MCF-7 and MDA-MB-231 cells. The bands related to the control (untreated) and MRC (100 $\mu \mathrm{M}, 24$ and $48 \mathrm{~h})$ groups of MCF-7 and MDA-MB-231 cells were quantified. Samples loading was adjusted to equalize total protein. The graphs represent the results of the quantification of PGP production which reveals a significant increase in the production of PGP in the MCF-7 cells; $\left(^{*}\right) p \leq 0.05$ 

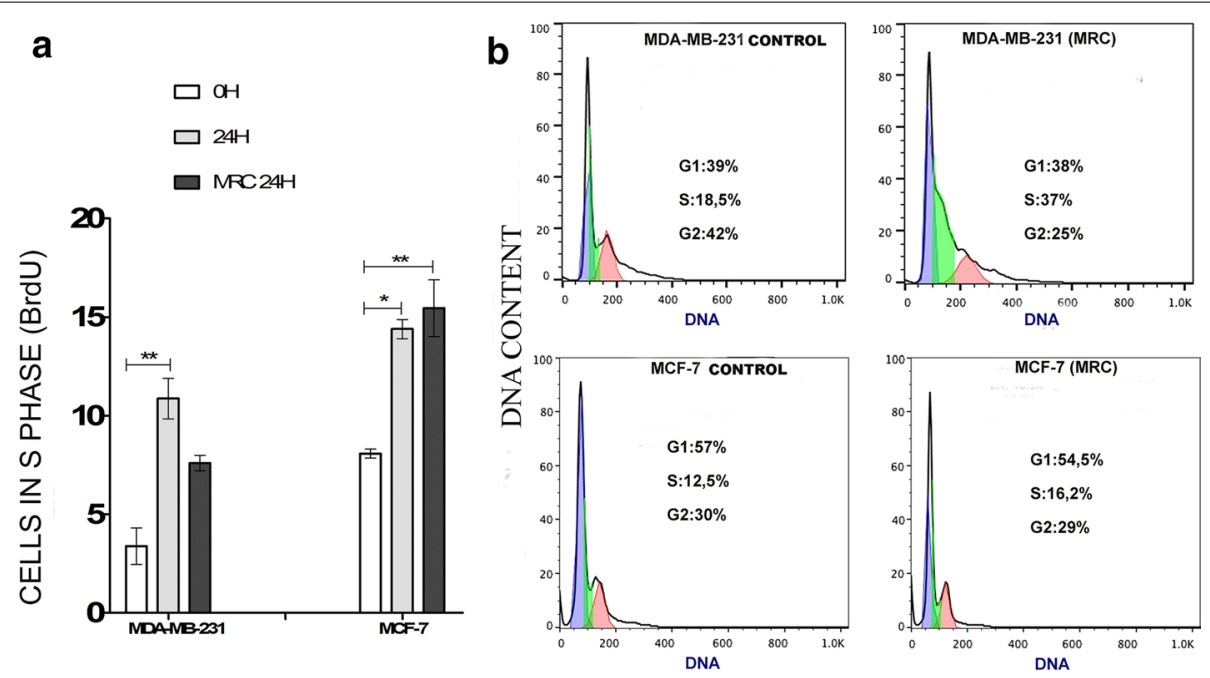

Fig. 4 Effects of exposure to MRC for $24 \mathrm{~h}$ on DNA synthesis and cell cycle of MDA-MB-231 and MCF-7 cells. a Number of cells treated with NPs ( $24 \mathrm{~h}$ ) in DNA synthesis ( $\mathrm{S}$ phase) compared to the untreated control ( $\mathrm{h} \mathrm{h}$ and $\left.24 \mathrm{~h}) .{ }^{*}\right) p \leq 0.05$; $\left.^{* *}\right) p \leq 0.01$. b Cell cycle assessment. Percentage of cells (treated with NPs with $100 \mu \mathrm{M}$ MRC by $24 \mathrm{~h}$ ) in gap 1 (G1), DNA synthesis (S) or gap 2 (G2) phase

ability of the cells. Therefore, the synthesis of drugs and nanomedicines that control this process should be stimulated (Jin et al. 2019). Although the involved mechanism is not yet understood, the reduction in migration of MDA-MB-231 cells treated with ruthenium-based metal complexes has been reported (Cao et al. 2015). In vitro reduction in the migration of metastatic breast cancer cells after treatment with NPs (Fig. 2) suggests an important action of MRC in the control of metastasis in remaining cells.

MCF-7 cells were less sensitive to the NP treatment. Studies have already demonstrated the induction of resistance in MCF-7 cells (Tsou et al. 2015). This feature in these cells can be related to data from the viability assay, which demonstrated a milder action on cytotoxicity over time. Studies indicate that increased expression of PGP protein is related to cell resistance (Nath et al. 2013; Jain 2008). It is also known that the high basal expression of this protein, as demonstrated in this study in MCF-7 compared to MDAMB-231 (Fig. 4), means a greater predisposition to multidrug resistance (Wishart et al. 1990). The high half-inhibitory concentration $\left(\mathrm{IC}_{50}\right)$ has also been related to a higher resistance index (Wu et al. 2014). In the present study, the MRC IC50 calculated for $24 \mathrm{~h}$ of treatment was 125 for MDA-MB-231 and $162 \mu \mathrm{M}$ for MCF-7. It has already been suggested that the efflux mechanism of NPs can be avoided by maintaining a high concentration of nanoparticles at the treatment site in a shorter incubation time (Panyam and Labhasetwar 2003). This relationship makes sense for MCF-7 cells, in which a reduction in sensitivity, NPs accumulation (Chaves et al. 2017) and an increase in expression of PGP proteins after $24 \mathrm{~h}$ of MRC exposure (Fig. 4). However, experiments focused on the molecular mechanisms involved in PGP transport are needed to better understand this process and to confirm the MDR effects related to MRC exposition in MCF-7 cells.

Many metal compounds reach the nuclei of cells causing changes that lead to cellular inviability (Zhang and Lippard 2003). This action, which may occur by means 
of inhibition of essential enzymes for cellular replication, or by impairment of DNA synthesis, has already been demonstrated in studies with free rhodium citrate (Erck et al. 1974; Zyngier et al. 1989). Our previous findings suggested that the action of $\mathrm{RC}$ in the nuclei of tumor cells seems to be kept after its association with maghemite nanoparticles (MRC) (Chaves et al. 2017). The occurrence of $S$ phase arrest with the use of MRC (Fig. 4), as observed in the present work, corroborates previous studies with free rhodium citrate.

The progression of the cell cycle is regulated by multiple checkpoints at different stages of the cell cycle. The three main ones are G1/S, G2/M and at the transition metaphase/anaphase during mitosis. Failure of this regulation can lead to abnormal growth or apoptosis. The G1/S checkpoint is the most critical for the control of cell proliferation by intracellular and extracellular signals related to the transport and integration of molecules in the nucleus (Skotheim et al. 2008). A positive relationship between the amount of cell cycle arrest at the $S$ phase and apoptosis was established (Zhu et al. 2014). In accordance, a previous study conducted by our group reported that MRC are capable of inducing MCF-7 cells to apoptosis (Chaves et al. 2015). Taken together, our data suggest that MRC nanoparticles accumulate in the nucleus of tumor cells, inhibiting DNA synthesis and cell proliferation and inducing cell death.

\section{Materials and method}

\section{Materials}

The magnetic fluids used were synthesized by the co-precipitation method of $\mathrm{Fe}^{2+}$ and $\mathrm{Fe}^{3+}$ ions in alkaline medium, subsequently oxidized by bubbling oxygen. The functionalized fluids of rhodium citrate associated with maghemite nanoparticles (MRC) and citrate-loaded maghemite nanoparticles (MC) were obtained by adsorption. MRC with $59.6 \mu \mathrm{M} \gamma-\mathrm{Fe}_{2} \mathrm{O}_{3}$ and $2.85 \mu \mathrm{M}$ rhodium citrate, $\mathrm{MC}$ with $64.7 \mu \mathrm{M} \gamma-\mathrm{Fe}_{2} \mathrm{O}_{3}$ and $2.55 \mu \mathrm{M}$ [citrate], and $2.513 \mathrm{mM}\left[\mathrm{Rh}_{2}\left(\mathrm{C}_{6} \mathrm{H}_{7} \mathrm{O}_{7}\right)_{4}\left(\mathrm{H}_{2} \mathrm{O}\right)_{2}\right.$ [rhodium (II) citrate] were synthesized at the Institute of Chemistry of the Goias Federal University (Goiania, Brazil). For maintenance of cell cultures, DMEM, RPMI and L15 mediums, fetal bovine serum (FBS) and $0.25 \%$ trypsin EDTA were used, and all were obtained from GIBCO Company-Life Technologies, Carlsbad, CA, USA, except Leibovitz's L15 (Sigma-Aldrich, St. Louis, MO, USA). The MRC solution diluted in $\mathrm{H}_{2} \mathrm{O}$ had a mean hydrodynamic diameter of $119.5 \mathrm{~nm}$ with a polydispersity index (PDI) of 0.17 , $\zeta$-potential of $-35 \mathrm{mV}$, analyzed by Zetasizer Nano ZS machine (Malvern, Malvern, UK) using a technology called dynamic light scattering (DLS), and similar values were maintained after subsequent measurements at different time intervals. The antibodies used in this study were: antiP-glycoprotein (monoclonal) produced in mice (Abcam, Cambridge, MA); anti-BrdU conjugated to Alexa Fluor 488 (Invitrogen Life Technologies, Carlsbad, CA, USA); HRPconjugated rabbit anti-mouse IgG (Sigma-Aldrich, St. Louis, MO, USA). The reagents used throughout the work were: MTT (3-[4,5-dimethyl-thiazol-2-yl]-2,5-diphenyltetrazolium bromide), DNAse (Sigma-Aldrich, St. Louis, MO, USA); bicinchoninic acid assay (BCA, Thermo Scientific, Rockford, IL); ATP (Invitrogen, San Diego, CA, USA). Inserts for invasion assay and basement membrane matrix $\left(\right.$ Matrigel $^{\mathrm{TM}}$ ) were purchased from BD Biosciences, San Jose, CA, USA. For Western blot analyses, we used a protease inhibitor (Hoffman-La Roche, Basel, Switzerland). The development was made with Amersham 
ECL prime Western blotting detection reagent, and image acquisition and analyses were performed with an Image Quant LAS 4000 (GE Healthcare, Little Chalfont, UK); further image processing and analysis were done with the ImageJ program (NIH, USA). For analysis of cell migration, an Axiovert light microscope $(5 \times$ magnification) was used and the images were captured with the AxioVision 100 software, both from Zeiss, Germany. The Spectramax M5 equipment and the data analyzed by the SoftMax Pro 5.2 program, both from Molecular Devices, LLC, USA, were used to read absorbances. The flow cytometer used was a FACS Calibur, BD Biosciences, Inc., San Jose, CA, and data analysis was performed on the Flow Jo v.5.2.7 program, Tree Star, Inc.

\section{Cell culture}

The human breast cancer cell lines MCF-7 and MDA-MB-231 were obtained from the American Type Culture Collection (ATCC) and cultured in Dulbecco's modified Eagle's medium and Leibovitz's L15 medium without $\mathrm{CO}_{2}$, respectively, containing $1 \%(\mathrm{v} / \mathrm{v})$ penicillin-streptomycin and $10 \%(\mathrm{v} / \mathrm{v})$ heat-inactivated fetal bovine serum (FBS). Primary cultures of human non-tumor mesenchymal cells from dental pulp (HNTMC) were obtained from health volunteers under approval of the Human Ethics Committee of the University of Brasilia (UnB). HNTMC were cultured with DMEM, supplemented with $10 \%(\mathrm{v} / \mathrm{v})$ heat-inactivated fetal bovine serum and $1 \%(\mathrm{v} / \mathrm{v})$ penicillin-streptomycin. HNTMC isolation was performed according to the following protocol: Extracted dental pulp was placed directly to a sterile tube containing DMEM, supplemented with $10 \%(\mathrm{v} / \mathrm{v})$ heat-inactivated fetal bovine serum and $1 \%(\mathrm{v} / \mathrm{v})$ penicillin-streptomycin until it was transferred to a plate ( 6 well) in the biological safety cabinet. To keep the cells fixes and facilitate adhesion to the bottom of the plate, a sterile pipette folded in half was used as a hook. The dental pulp received culture medium DMEM and was maintained at $37^{\circ} \mathrm{C}, 5 \% \mathrm{CO}_{2}$ and $80 \%$ of humidity. A half of the culture medium was replaced twice a week, until the cells reach confluency (80-90\%). Then, the adherent cells were dissociated with trypsin and were frozen as seed stock in the presence of a cryoprotective agent dimethylsulfoxide (DMSO).

\section{In vitro cytotoxicity study}

In order to understand how the cells respond to MRC nanoparticles, MDA-MB-231, MCF-7 and HNTMC cells were incubated for 24,48 and $72 \mathrm{~h}$ with various concentrations of this compound. Furthermore, the tumor cells were also exposed to free rhodium citrate (RC) at the same concentrations as those in MRC. Viability of the cells after exposure to NPs and RC was evaluated by use of the MTT assay according to the manufacturer's recommendations (Invitrogen Life Technologies, Carlsbad, CA, USA). Briefly, $1 \times 10^{4}$ cells/well were seeded in 96-well plates and exposed to the treatments at the concentrations of $50 \mu \mathrm{M}, 100 \mu \mathrm{M}, 200 \mu \mathrm{M}$ (rhodium citrate). All experiments were repeated at least three times in triplicates and were preceded by kinetic tests to adjust the initial cells amount for each exposure time and to avoid the control group confluency at later time of exposition. Results were expressed as percent of viability (\%V) according to the following formula (blank discounted): $\% V=$ absorbance $($ cells + medium $+\mathrm{NPs})-$ absorbance (medium + NPs). After cell treatment, the medium was removed from each well and replaced with new medium containing MTT (15 $\mu$ of 
MTT solution at $5 \mathrm{mg} / \mathrm{ml}$ and $135 \mu \mathrm{l}$ of culture medium) for two and a half hours at $37{ }^{\circ} \mathrm{C}$ in a humidified atmosphere with $5 \% \mathrm{CO}_{2}$. The resulting formazan product was dissolved in $200 \mu \mathrm{l}$ of dimethylsulfoxide (DMSO, Sigma-Aldrich, St. Louis, MO, USA). Afterward, the supernatants of each sample were transferred to a fresh 96-well plate (to avoid interference of nanoparticles that did not enter the cells and accumulate on the bottom of wells), and absorbance was measured by a spectrophotometer (SpectraMax M2, Molecular Devices, Sunnyvale, CA, USA) at the wavelength of $595 \mathrm{~nm}$.

\section{Cell migration test}

To assess the migration/invasion capacity of MDA-MB-231, the cells were treated with MRC and plated $\left(1 \times 10^{6}\right)$ in $25-\mathrm{cm}^{2}$ flasks for $24 \mathrm{~h}$. Treatment with $200 \mu \mathrm{M}$ nanoparticles was performed in the culture flasks for $24 \mathrm{~h}$. Cell viability was evaluated by means of trypan blue assay. The cells were trypsinized, resuspended $\left(2 \times 10^{4}\right)$ in L15 medium without fetal bovine serum (FBS) and added to the top of inserts (Transwell for 24-well plates, BD Biosciences) with $8-\mu \mathrm{m}$ pores coated with a thin layer (30 $\mu \mathrm{l})$ of Matrigel $^{\mathrm{TM}}$ (BD Biosciences) diluted $5 \times$ in frozen fetal bovine serum-free L15 medium. The plate was left for $1 \mathrm{~h}$ at $37{ }^{\circ} \mathrm{C}$ for solidification of the Matrigel layer. In the wells of the plate, below the inserts, the L15 medium was supplemented with 10\% SFB to attract a migration of the cells through the pores. After $48 \mathrm{~h}$, the inserts were removed from the plate and the cells that adhered to the top of the Transwell (which did not migrate) were removed with a cotton swab. Cells remaining in the lower part of the insert were fixed (3.7\% paraformaldehyde, $15 \mathrm{~min}$ ) and stained with $0.1 \%$ crystal violet for $5 \mathrm{~min}$. All stained cells were photographed ( $5 \times$ magnification), and an invasiveness rate was given by automated counting of cells processed with the ImageJ software.

\section{The effect of MRC nanoparticles on DNA synthesis}

For analysis of DNA replication and cell cycle, $5 \times 10^{5}$ MDA-MB-231 and MCF-7 cells were plated in 6-well plates $\left(10 \mathrm{~cm}^{2}\right)$ in appropriate medium. After adherence, medium was exchanged for another containing $10 \mu \mathrm{M}$ bromodeoxyuridine (BrdU) and incubated for $2 \mathrm{~h}$ at $37{ }^{\circ} \mathrm{C}$ for incorporation of BrdU into the DNA. As a negative control, one group did not receive BrdU. Subsequently, the cells received new medium, and in the experimental group, nanoparticles containing $200 \mu \mathrm{M}$ MRC were added, and the treatment lasted for $24 \mathrm{~h}$. The group which did not receive the treatment was considered the zero point and was collected immediately after incorporation of BrdU, and processed until the overnight fixation step at $4{ }^{\circ} \mathrm{C}$. The cells were trypsinized and centrifuged at $1500 \mathrm{rpm}$ for $5 \mathrm{~min}$. The medium was discarded, and MDA-MB-231 cells were washed with ice-cold phosphate-buffered saline (PBS) and fixed with $70 \%$ ice-cold ethanol for $30 \mathrm{~min}$. The fixative solution was removed, and DNAse $(0.3 \mathrm{mg} / \mathrm{ml})$ was added for 10 to $15 \mathrm{~min}$ for denaturation of the DNA at $37^{\circ} \mathrm{C}$. After discarding the solution containing DNAse, the pellet was resuspended in blocking solution (30 min) containing $50 \mu \mathrm{l}$ of Tween 20 and 1\% serum albumin (BSA)/PBS. Samples were incubated for $1 \mathrm{~h}$ with primary anti-BrdU antibody (1:100), and after 45 min with FITC-conjugated secondary antibody $(1: 10,000)$ in a solution containing $5 \mu \mathrm{l}$ of RNAse $(10 \mathrm{mg} / \mathrm{ml})$. Subsequently, the pellet was resuspended in $1 \mathrm{ml}$ with $5 \mu \mathrm{g} / \mathrm{ml}$ propidium iodide (PI) for $10 \mathrm{~min}$. The cells $(10,000$ of each group in triplicate) were analyzed on a flow cytometer. 


\title{
Immunoblotting analysis
}

For western blot, MDA-MB-231, MCF-7 and HNTMC cells $\left(1 \times 10^{6}\right)$ were grown in flasks. Fresh medium with $100 \mu \mathrm{M}$ MRC was added to the flasks, which were incubated for $6 \mathrm{~h}$ at $37^{\circ} \mathrm{C}$. Cells were rinsed three times in ice-cold PBS, and protein extraction was performed with lysis buffer ( $50 \mathrm{mM}$ Tris pH 7,4; $150 \mathrm{mM} \mathrm{NaCl} ; 5 \mathrm{mM}$ ethylenediamine tetraacetic acid (EDTA); and 1\% Triton X100 and protease inhibitor cocktail). Lysates were centrifuged $\left(10 \mathrm{~min}, 4{ }^{\circ} \mathrm{C}\right)$. Protein concentrations were determined by the bicinchoninic acid assay. Protein total lysates $(20 \mu \mathrm{g})$ were separated by $4-12 \%$ gradient sodium dodecyl sulfate-polyacrylamide gel electrophoresis (SDS-PAGE) and transferred to a nitrocellulose membrane. Membranes were blocked with 5\% nonfat dry milk in Tris-buffered saline (TBS) $-0.1 \%$ Tween, followed by incubation with primary (1:1000 anti-P-glycoprotein) and secondary (goat anti-mouse HRP-1:5000) antibodies. Development was performed by ECL chemiluminescence kit. The experiment was repeated three times.

\section{Statistical analysis}

The quantitative data were submitted to the ' $t$ ' test for unpaired samples (between two groups) or simple variance (ANOVA) (between three or more groups) followed by the Bonferroni post-test. Statistical analyses were conducted using the GraphPad Prism software, and the results were expressed as mean \pm SEM. Values of $p<0.05$ were considered statistically significant.

\section{Conclusions}

The MRC cytotoxicity effect was dependent on concentration and time of exposure in MDA-MB-23 cells, whereas prolonged exposure was not effective in MCF-7 cells. Together, the data suggest that MRC act at the nucleus, inhibiting DNA synthesis and proliferation and inducing cell death. These effects were verified in both tumor lines, but MDA-MB-231 (metastatic cells) appears to be more susceptible to the effects of MRC. In addition, NPs may also act on the metastatic activity of remaining cells, reducing their migratory capacity. Our results suggest that MRC nanoparticles are a promising nanomaterial that can provide a convenient route for tumor targeting and treatment.

\begin{abstract}
Abbreviations
ATCC: American Type Culture Collection; BrdU: bromodeoxyuridine; BSA: serum albumin; DLS: dynamic light scattering; DMEM: Dulbecco's modified Eagle medium; DMSO: dimethylsulfoxide; DNA: deoxyribonucleic acid; EDTA: ethylenediaminetetraacetic acid; EPR: enhanced permeability and retention effect; FBS: fetal bovine serum; G1: gap 1 phase; G2: gap 2 phase; HNTMC: human non-tumor mesenchymal cells; IC50: half maximal inhibitory concentration; L15: Leibovitz's L15 medium; MC: citrate-loaded maghemite nanoparticles; MDR: multidrug resistance; $\mu \mathrm{M}$ : micromolar; MRC: maghemite nanoparticles with rhodium citrate; MTT: (3-[4,5-dimethyl-thiazol-2-yl]-2,5-diphenyltetrazolium bromide); NPs: nanoparticles; PBS: phosphate-buffered saline; PDI: polydispersity index; PGP: P-glycoprotein; RC: rhodium citrate; RPMI: Roswell Park Memorial Institute; SDS-PAGE: sodium dodecyl sulfate-polyacrylamide gel electrophoresis; $S$ phase: synthesis phase.
\end{abstract}

\section{Acknowledgements}

Not applicable.

\section{Authors' contributions}

NLC was the principal investigator and took primary responsibility for the paper. NLC, DAA, CAPL, IE-L, JB, ARdS and SNB participated in the design and coordination of the study. DAA participated on experimental design and execution concerning the MTT and BrDU analyses. CAPL performed the counting and interpretation of invasiveness rate of migrated cells processed with the ImageJ software. IE-L and JB coordinated the in vitro assays and helped draft the manuscript. 
ARdS synthesized drugs and nanoparticles used in this research. NLC, CAPL and SNB wrote the manuscript, and all of the authors helped discuss the results, adding thoughtful insights. All authors read and approved the final manuscript.

\section{Funding}

The author gratefully acknowledges financial support from the Brazilian Research agencies FINEP, FAPDF, CNPq and CAPES.

\section{Availability of data and materials}

The datasets used and/or analyzed during the current study are available from the corresponding author on reasonable request.

\section{Ethics approval and consent to participate}

The research involving primary cultures of human non-tumor mesenchymal cells (HNTMC) from dental pulp was obtained from health volunteers, who provided informed consent, and with approval from the Human Ethics Committee of the University of Brasilia (104934/2008).

\section{Consent for publication}

Not applicable.

\section{Competing interests}

We confirm that we have given due consideration to the protection of intellectual property associated with this work and that there are no impediments to publication, including the timing of publication, with respect to intellectual property. The authors declare that they have no competing interests.

\section{Author details}

${ }^{1}$ Institute of Biological Sciences, Department of Cell Biology, University of Brasilia (UnB), Brasilia, Brazil. ${ }^{2}$ Department of Life Sciences Applied Metrology, National Institute of Metrology, Quality and Technology, Duque de Caxias, Brazil. ${ }^{3}$ Institute of Biophysics and Medical Physics, University of Leipzig, Leipzig, Germany. ${ }^{4}$ Institute of Chemistry, Federal University of Goias, Goiania, Brazil.

Received: 31 May 2019 Accepted: 21 August 2019

Published online: 11 September 2019

\section{References}

Bana E, Bagrel D. In vitro breast cancer models as useful tools in therapeutics? Breast cancer-focusing tumor micro environment, stem cells metastasis. New York: IntechOpen; 2011.

Bender P, Fock J, Hansen M, Bogart L, Southern P, Ludwig F, Wiekhorst F, Szczerba W, Zeng L, Heinke D. Influence of clustering on the magnetic properties and hyperthermia performance of iron oxide nanoparticles. Nanotechnology. 2018;29:425705. https://doi.org/10.1088/1361-6528/aad67d.

Cao W, Zheng W, Chen T. Ruthenium polypyridyl complex inhibits growth and metastasis of breast cancer cells by suppressing FAK signaling with enhancement of TRAlL-induced apoptosis. Sci Rep. 2015;5:9157. https://doi. org/10.1038/srep09157.

Carneiro MLB, Nunes ES, Peixoto RCA, Oliveira RGS, Lourenço LHM, da Silva ICR, Simioni AR, Tedesco AC, de Souza AR, Lacava ZGM. Free Rhodium (II) citrate and rhodium (II) citrate magnetic carriers as potential strategies for breast cancer therapy. J Nanobiotechnol. 2011;9:11.

Chaves NL, Lopes CAP, Carneiro MLB, de Souza AR, da Silva MO, Corrêa JR, Báo SN. Rhodium citrate associated with maghemite nanoparticles causes DNA fragmentation independently of caspases 3 and mediated by reactive oxygen species. J Nanomed Nanotechnol. 2015;6:1. https://doi.org/10.4172/2157-7439.1000312.

Chaves NL, Estrela-Lopis I, Böttner J, Lopes CA, Guido BC, de Sousa AR, Báo SN. Exploring cellular uptake of iron oxide nanoparticles associated with rhodium citrate in breast cancer cells. Int J Nanomed. 2017;12:5511. https://doi. org/10.1186/1477-3155-9-11.

Chen H-P, Lee Y-K, Huang SY, Shi P-C, Hsu P-C, Chang C-F. Phthalate exposure promotes chemotherapeutic drug resistance in colon cancer cells. Oncotarget. 2018;9:13167. https://doi.org/10.18632/oncotarget.23481.

Cheng W, Liang C, Xu L, Liu G, Gao N, Tao W, Luo L, Zuo Y, Wang X, Zhang X. TPGS-functionalized polydopamine-modified mesoporous silica as drug nanocarriers for enhanced lung cancer chemotherapy against multidrug resistance. Small. 2017;13(29):1700623. https://doi.org/10.1002/smll.201700623.

Cook D, Brown D, Alexander R, March R, Morgan P, Satterthwaite G, Pangalos MN. Lessons learned from the fate of AstraZeneca's drug pipeline: a five-dimensional framework. Nat Rev Drug Discovery. 2014;13:419. https://doi. org/10.1038/nrd4309.

Da Silva Nunes E, Carneiro MLB, De Oliveira RGS, Báo SN, De Souza AR. Colloidal stability, surface characterisation and intracellular accumulation of Rhodium (II) citrate coated superparamagnetic iron oxide nanoparticles in breast tumour: a promising platform for cancer therapy. J Nanopart Res. 2013;15:1683. https://doi.org/10.1007/s1105 1-013-1683-5.

Eastman A. Improving anticancer drug development begins with cell culture: misinformation perpetrated by the misuse of cytotoxicity assays. Oncotarget. 2017;8:8854. https://doi.org/10.18632/oncotarget.12673.

Erck A, Rainen L, Whileyman J, Chang I, Kimball A, Bear J. Studies of rhodium (II) carboxylates as potential antitumor agents. Proc Soc Exp Biol Med Soc Exp Biol Med. 1974. https://doi.org/10.3181/00379727-145-37996.

Hare Jl, Lammers T, Ashford MB, Puri S, Storm G, Barry ST. Challenges and strategies in anti-cancer nanomedicine development: an industry perspective. Adv Drug Deliv Rev. 2017;108:25-38. https://doi.org/10.1016/j.addr.2016.04.025. 
Harmon TL, Harbuzariu A, Yang L, Gonzalez-Perez RR. Iron oxide nanoparticle-leptin receptor antagonist: a novel targeted adjuvant therapy for triple negative breast cancer. AACR. 2015. https://doi.org/10.1158/1538-7445.AM2015-3909.

Iv M, Telischak N, Feng D, Holdsworth SJ, Yeom KW, Daldrup-Link HE. Clinical applications of iron oxide nanoparticles for magnetic resonance imaging of brain tumors. Nanomedicine. 2015;10:993-1018. https://doi.org/10.2217/ nnm.14.203.

Jain KK. Recent advances in nanooncology. Technol Cancer Res Treat. 2008;7:1-13. https://doi.org/10.1016/j. ejso.2016.06.049.

Jin J, Krishnamachary B, Barnett JD, Chatterjee S, Chang D, Mironchik Y, Wildes F, Jaffee E, Nimmagadda S, Bhujwalla ZM. Human cancer cell membrane coated biomimetic nanoparticles reduce fibroblast-mediated invasion and metastasis, and induce T cells. ACS Appl Mater Interfaces. 2019. https://doi.org/10.1021/acsami.8b22309.

Karakatsanis A, Christiansen P, Fischer L, Hedin C, Pistioli L, Sund M, Rasmussen N, Jørnsgård H, Tegnelius D, Eriksson S. Super paramagnetic iron oxide nanoparticles for sentinel node detection in patients with breast cancer: experience from seven centres in Sweden and Denmark. Eur J Surg Oncol. 2016;42:S83.

Liang C, Wang H, Zhang M, Cheng W, Li Z, Nie J, Liu G, Lian D, Xie Z, Huang L. Self-controlled release of Oxaliplatin prodrug from d-a-tocopheryl polyethylene glycol 1000 succinate (TPGS) functionalized mesoporous silica nanoparticles for cancer therapy. J Colloid Interface Sci. 2018;525:1-10. https://doi.org/10.1016/j.jcis.2018.04.058.

Low SK, Zembutsu H, Nakamura Y. Breast cancer: the translation of big genomic data to cancer precision medicine. Cancer Sci. 2018;109:497-506. https://doi.org/10.1111/cas.13463.

Maeda $\mathrm{H}$, Nakamura H, Fang J. The EPR effect for macromolecular drug delivery to solid tumors: improvement of tumor uptake, lowering of systemic toxicity, and distinct tumor imaging in vivo. Adv Drug Deliv Rev. 2013;65:71-9. https:// doi.org/10.1177/153303460800700101.

Magro M, Baratella D, Bonaiuto E, De A roger J, Vianello F. New perspectives on biomedical applications of iron oxide nanoparticles. Curr Med Chem. 2018;25:540-55. https://doi.org/10.2174/0929867324666170616102922.

Manikandan K, Santhanam A, Anand SB. Maghemite nanoparticle induced DNA damage and oxidative stress mediated apoptosis of CRL-1739 adenogastric carcinoma cell. Curr Nanomed. 2018;8:58-68. https://doi.org/10.2174/24681 87307666170719163711.

Nath S, Daneshvar K, Roy L, Grover P, Kidiyoor A, Mosley L, Sahraei M, Mukherjee P. MUC1 induces drug resistance in pancreatic cancer cells via upregulation of multidrug resistance genes. Oncogenesis. 2013;2:e51. https://doi. org/10.1038/oncsis.2013.16.

Panyam J, Labhasetwar V. Dynamics of endocytosis and exocytosis of poly ( $D$, L-lactide-co-glycolide) nanoparticles in vascular smooth muscle cells. Pharm Res. 2003;20:212-20. https://doi.org/10.1023/A:1022219003551.

Paris JL, Vallet-Regí M. Nanostructures for imaging, medical diagnostics and therapy. Fundamentals of nanoparticles. Amsterdam: Elsevier; 2018. https://doi.org/10.1016/B978-0-323-51255-8.00001-X.

Peixoto RC, Miranda-Vilela AL, de Souza Filho J, Carneiro ML, Oliveira RG, da Silva MO, de Souza AR, Báo SN. Antitumor effect of free rhodium (II) citrate and rhodium (II) citrate-loaded maghemite nanoparticles on mice bearing breast cancer: a Systemic toxicity assay. Tumor Biol. 2015;36:3325-36.

Peng Y, Nie J, Cheng W, Liu G, Zhu D, Zhang L, Liang C, Mei L, Huang L, Zeng X. A multifunctional nanoplatform for cancer chemo-photothermal synergistic therapy and overcoming multidrug resistance. Biomater Sci. 2018;6(5):1084-98. https://doi.org/10.1039/c7bm01206c.

Rocha M, Arcanjo R, Lopes C, Carneiro M, Souza A, Báo S. Modulation of fibronectin and laminin expression by Rhodium (II) citrate-coated maghemite nanoparticles in mice bearing breast tumor. Sci Rep. 2017;7:17904. https://doi. org/10.1038/s41598-017-18204-1.

Shi J, Kantoff PW, Wooster R, Farokhzad OC. Cancer nanomedicine: progress, challenges and opportunities. Nat Rev Cancer. 2017;17:20. https://doi.org/10.1038/nrc.2016.108.

Skotheim JM, di Talia S, Siggia ED, Cross FR. Positive feedback of G1 cyclins ensures coherent cell cycle entry. Nature. 2008:454:291. https://doi.org/10.1038/nature07118.

Tsou S-H, Chen T-M, Hsiao H-T, Chen Y-H. A critical dose of doxorubicin is required to alter the gene expression profiles in MCF-7 cells acquiring multidrug resistance. PLoS ONE. 2015;10:e0116747. https://doi.org/10.1371/journ al.pone.0116747.

Wicki A, Witzigmann D, Balasubramanian V, Huwyler J. Nanomedicine in cancer therapy: challenges, opportunities, and clinical applications. J Control Release. 2015;200:138-57. https://doi.org/10.1016/j.jconrel.2014.12.030.

Wishart G, Plumb J, Going J, McNicol A, McArdle C, Tsuruo T, Kaye S. P-glycoprotein expression in primary breast cancer detected by immunocytochemistry with two monoclonal antibodies. Br J Cancer. 1990;62:758. https://doi. org/10.1038/bjc.1990.373.

Wu Q, Yang Z, Nie Y, Shi Y, Fan D. Multi-drug resistance in cancer chemotherapeutics: mechanisms and lab approaches. Cancer Lett. 2014;347:159-66. https://doi.org/10.1016/j.canlet.2014.03.013.

Zhang CX, Lippard SJ. New metal complexes as potential therapeutics. Curr Opin Chem Biol. 2003;7:481-9. https://doi. org/10.1016/S1367-5931(03)00081-4.

Zhu Q, Hu J, Meng H, Shen Y, Zhou J, Zhu Z. S-Phase cell cycle arrest, apoptosis, and molecular mechanisms of aplasia ras homolog member I-induced human ovarian cancer SKOV3 cell lines. Int J Gynecol Cancer. 2014;24:629-34. https:// doi.org/10.1097/IGC.0000000000000105.

Zyngier S, Kimura E, Najjar R. Antitumor effects of Rhodium (II) citrate in mice bearing Chrlich tumors. Braz I Med Biol Res. 1989;22:397-401.

\section{Publisher's Note}

Springer Nature remains neutral with regard to jurisdictional claims in published maps and institutional affiliations. 